\title{
Use of newly isolated phages for control of Pseudomonas aeruginosa PAO1 and ATCC 10145 biofilms
}

\author{
Diana Pires $^{\text {a }}$, Sanna Sillankorva ${ }^{\mathrm{a}}$, Alberta Faustino ${ }^{\mathrm{b}}$, Joana Azeredo ${ }^{\mathrm{a}, *}$ \\ ${ }^{a}$ IBB - Institute of Biotechnology and Bioengineering, Center of Biological Engineering, University of Minho, Campus de Gualtar 4710-057, Braga, Portugal \\ ${ }^{\mathrm{b}}$ São Marcos Hospital, P.O. box 2242, 4701-965 Braga, Portugal
}

Received 25 June 2010; accepted 9 May 2011

Available online 5 July 2011

\begin{abstract}
Pseudomonas aeruginosa is a relevant opportunistic pathogen involved in nosocomial infections that frequently shows low antibiotic susceptibility. One of its virulence factors is associated with the ability to adhere to surfaces and form virulent biofilms. This work describes the isolation and characterization of lytic phages capable of infecting antibiotic-resistant $P$. aeruginosa strains. In addition, characterization of P. aeruginosa biofilms and the potential of newly isolated phages for planktonic and biofilm control was accessed. According to the results, the isolated phages showed different spectra of activity and efficiency of lysis. Four broad lytic phages were selected for infection of planktonic cells; however, despite their broad range of activity, two of the selected phages failed to efficiently control planktonic cultures. Therefore, only two phages (phiIBB-PAA2 and phiIBB-PAP21), highly capable of causing strong biomass reduction of planktonic cells, were tested against $24 \mathrm{~h}$ biofilms using a m.o.i. of 1 . Both phages reduced approximately $1-2 \log$ the biofilm population after $2 \mathrm{~h}$ of infection and reduction was further enhanced after $6 \mathrm{~h}$ of biofilm infection. However, biofilm cells of $P$. aeruginosa PAO1 acquired resistance to phiIBB-PAP21; consequently, an increase in the number of cells after $24 \mathrm{~h}$ of treatment was observed. Conversely, phage phiIB-PAA2 for P. aeruginosa ATCC10145 continued to destroy biofilm cells, even after $24 \mathrm{~h}$ of infection. In these biofilms, phages caused a $3 \log$ reduction in the number of viable counts of biofilm cells.
\end{abstract}

(C) 2011 Institut Pasteur. Published by Elsevier Masson SAS. All rights reserved.

Keywords: Pseudomonas aeruginosa; Bacteriophages; Biofilms; Control

\section{Introduction}

Pseudomonas aeruginosa is an ubiquitous organism which has emerged as a major threat in the hospital environment. This bacterium is the most frequently isolated Gram-negative organism in bloodstream and wound infections, pneumonia and intra-abdominal and urogenital sepsis, and is a serious problem, infecting immunocompromised patients with cystic fibrosis (CF), severe burns, cancer, AIDS, etc. (Driscoll et al., 2007; Page and Heim, 2009). One of the most worrying characteristics of this bacterium is its low antibiotic

\footnotetext{
* Corresponding author.

E-mail addresses: priscilapires@deb.uminho.pt (D. Pires), s.sillankorva@ deb.uminho.pt (S. Sillankorva), afaustino@bluebottle.com (A. Faustino), jazeredo@deb.uminho.pt (J. Azeredo).
}

susceptibility, which can be attributed to a concerted action of multidrug efflux pumps with chromosomally-encoded antibiotic resistance genes and the low permeability of the bacterial cellular envelopes (Lambert, 2002).

Overuse of antibiotics has also significantly increased the emergence of antimicrobial multiresistant bacteria; consequently, treatment of most chronic P. aeruginosa infections with antibiotics is notoriously difficult (Cunha, 2002; Lambert, 2002). Additionally, P. aeruginosa has an innate ability to adhere to surfaces and form virulent biofilms particularly difficult to eradicate (Drenkard, 2003; Mah et al., 2003; Stewart and Costerton, 2001). Biofilm formation is an important bacterial survival strategy and, in humans, biofilms are responsible for numerous pathologies usually associated with use of medical devices (Azeredo and Sutherland, 2008; Donlan, 2002; O'Toole et al., 2000). Thus, new alternative 
strategies to antibiotherapy are highly in demand by the worldwide medical and scientific community. Bacteriophages (phages) are the natural enemies of bacteria and might represent one attractive solution to this problem (Clark and March, 2006; Joerger, 2003; Sulakvelidze, 2005).

Phage therapy is based on the use of lytic phages to combat bacterial infections, including multidrug-resistant bacteria, and has many advantages comparated to antibiotics: they are very specific and efficient for their target bacteria, which reduces destruction of the host's natural flora; they are not pathogenic for man; and they persist only as long as the targeted bacteria are present (Azeredo and Sutherland, 2008; Clark and March, 2006; Matsuzaki et al., 2005; Skurnik and Strauch, 2006).

Here we describe the isolation and characterization of novel phages for $P$. aeruginosa and their application to planktonic cultures and biofilms. The main goal is to determine phage potential to control these two types of cells.

\section{Materials and methods}

\subsection{Bacterial strains and culture conditions}

Thirty-five strains of $P$. aeruginosa were used in this work: 4 strains for isolation of phages - ATCC 10145, CECT 111, PAO1 and a clinical isolate (CLIN) (isolated from an endoscope, Rouen, France) - and 31 strains for evaluating the lytic spectra of the isolated phages. These 31 strains were clinical isolates provided by the Hospital de Braga (Braga, Portugal). Bacteria were grown at $37{ }^{\circ} \mathrm{C}$ in tryptic soy broth (TSB, Merck) or in tryptic soy agar (TSA, Merck). Biofilm assays were performed using yeast peptone dextrose (YPD - $10 \mathrm{~g} \mathrm{l}^{-1}$ yeast extract, $20 \mathrm{~g} \mathrm{l}^{-1}$ peptone, $20 \mathrm{~g} \mathrm{l}^{-1}$ dextrose).

\subsection{Isolation of phages}

Bacteriophages were isolated from 2 hospital effluents provided by the Hospital de São João (Porto, Portugal). These effluents were enriched with 4 bacterial hosts (ATCC 10145, CECT 111, PAO1 and a clinical isolate) in $2 \times$ TSB medium. This solution was incubated $\left(37^{\circ} \mathrm{C}, 120 \mathrm{rpm}\right)$ for $48 \mathrm{~h}$ and then centrifuged to collect supernatant for spot tests indicative of the existence of phage(s). Each inhibition halo was further purified with toothpicks and paper to isolate all different phages. All morphologically different phage plaques were purified until de Petri plates presented a single plaque morphology. Five similar plaques of each isolated phage were measured and characteristics are presented in Table 1.

\subsection{Production of phages}

The production of phages in Petri plates consists of immersing a paper strip in a solution containing phage and passing it on a top-agar layer containing the proper bacterial strain. The plates were incubated for $16-18 \mathrm{~h}$ at $37{ }^{\circ} \mathrm{C}$; then, $3 \mathrm{ml}$ of SM buffer $\left(5.8 \mathrm{~g} \mathrm{l}^{-1} \mathrm{NaCl}, 2 \mathrm{~g} \mathrm{l}^{-1} \mathrm{MgSO}_{4} \cdot 7 \mathrm{H}_{2} \mathrm{O}\right.$, $50 \mathrm{ml} \mathrm{l}^{-1} 1 \mathrm{M}$-tris- $\left.\mathrm{HCl} \mathrm{pH} 7.5\right)$ were added. The plates were
Table 1

Characterization of the different $P$. aeruginosa phage plaques.

\begin{tabular}{lllll}
\hline Host & Phage (philBB-...) & Diameter $(\mathrm{mm})^{\mathrm{a}}$ & Turbidity & Halo \\
\hline ATCC 10145 & PAA2 & 1 & $\mathrm{~T}$ & - \\
CECT 111 & PAC222 & 2 & $\mathrm{~T}$ & - \\
& PAC2211 & 1.5 & $\mathrm{~T}$ & - \\
& PAC2212 & 1 & $\mathrm{C}$ & + \\
& PAC111 & 2.5 & $\mathrm{C}$ & + \\
& PAC23 & 1.5 & $\mathrm{~T}$ & - \\
PAO 1 & PAC24 & 4 & $\mathrm{C}$ & - \\
& PAP2222 & 2 & $\mathrm{C}$ & + (large) \\
& PAP21 & 1 & $\mathrm{~T}$ & - \\
& PAP2221 & 2.5 & $\mathrm{C}$ & + (large) \\
& PAP221 & 1.5 & $\mathrm{~T}$ & - \\
CLIN & PAP121 & 2 & $\mathrm{C}$ & - \\
& PACL212 & 1 & $\mathrm{C}$ & + \\
& PACL211 & 3 & $\mathrm{C}$ & + \\
& PACL22 & 3 & $\mathrm{C}$ & + \\
& PACL11 & 1 & $\mathrm{~T}$ & - \\
& PACL12 & 2 & $\mathrm{~T}$ & - \\
\hline
\end{tabular}

T: turbid; C: clear; + presence of halo; - no visible halo.

a Mean diameter of 5 different phage plaques measured.

placed under agitation (120 rpm) at $4{ }^{\circ} \mathrm{C}$ for $16-18 \mathrm{~h}$; afterwards, liquid and top-agar were collected, centrifuged and the supernatant was filtrated $(0.2 \mu \mathrm{m})$.

\subsection{Selection of phages}

The selection of the 4 best phages (one for each host) was done according to results of lytic spectra. To evaluate lytic spectra of all isolated phages, they were tested against 35 strains of $P$. aeruginosa. One drop of each serial diluted phage suspension, with titers of about $10^{4}$ to $10^{7} \mathrm{PFU} \mathrm{ml}{ }^{-1}$, was placed on the different bacterial lawns and incubated overnight at $37{ }^{\circ} \mathrm{C}$. The following day, the susceptibility of each host to the different phages was evaluated.

\subsection{Infection of planktonic cells}

Infection of planktonic cells was done at two different stages of bacterial growth - exponential and stationary phases. To induce planktonic cell infections at the stationary stage, the 4 hosts were inoculated overnight in TSB medium at $37{ }^{\circ} \mathrm{C}(120 \mathrm{rpm})$. The resulting cell suspensions were diluted with TSB medium to obtain an optical density $\left(\mathrm{OD}_{600 \mathrm{~nm}}\right)$ of approximately 0.75 , which corresponds to approximately $1.32 \times 10^{9}, 1.11 \times 10^{9}, 1.28 \times 10^{9}$ and $8.71 \times 10^{8} \mathrm{CFU} \mathrm{ml}^{-1}$ of $P$. aeruginosa ATCC 10145, CECT 111, CLIN and PAO1, respectively. To carry out planktonic cell infection at exponential stage, an overnight pre-inoculum was used to inoculate $100 \mathrm{ml}$ of fresh TSB medium, which were allowed to grow to an optical density $\left(\mathrm{OD}_{600 \mathrm{~nm}}\right)$ of 0.5 , which corresponds to approximately $8.63 \times 10^{8}, 7.42 \times 10^{8}, 8.67 \times 10^{8}$ and $6.21 \times 10^{8} \mathrm{CFU} \mathrm{ml}{ }^{-1}$ of $P$. aeruginosa ATCC 10145, CECT 111, CLIN and PAO1, respectively. The suspensions were centrifuged and resuspended in fresh TSB media in obtain an $\mathrm{OD}_{600 \mathrm{~nm}}$ of 0.75 which allows better comparison of the two different assays performed. In all experiments, $125 \mu \mathrm{l}$ of 
phages were added to $125 \mu \mathrm{l}$ of suspensions of the respective hosts in order to obtain a multiplicity of infection (m.o.i.) of 1 . The control experiments were performed with SM buffer instead of phages. The infection of planktonic cell assays were performed in 96-well microtiter plates. The plates were placed into an orbital incubator $(120 \mathrm{rpm})$ at $37{ }^{\circ} \mathrm{C}$ and the optical density $\left(\mathrm{OD}_{600 \mathrm{~nm}}\right)$ was regularly read. Three independent experiments were performed in duplicate.

\subsection{Biofilm formation}

Based on phage infection experiments on planktonic cells, only P. aeruginosa ATCC 10145 and PAO1 strains were used in biofilm assays. Biofilm formation was carried out in 24-well microplates containing $1 \mathrm{ml}$ of YPD medium and $10 \mu \mathrm{l}$ of cellular suspension with an $\mathrm{OD}_{600 \mathrm{~nm}}$ of 1.0 which corresponds to approximately $1.9 \times 10^{9}$ and $1.1 \times 10^{9} \mathrm{CFU} \mathrm{ml}{ }^{-1}$, respectively. Biofilms were formed for 24 and $48 \mathrm{~h}$ with medium renewal every $12 \mathrm{~h}$. The plates were incubated at $37{ }^{\circ} \mathrm{C}$ in an orbital shaker $(120 \mathrm{rpm})$. Three independent experiments were performed in duplicate.

\subsection{Crystal violet assay}

Total biomass attached to each well was measured by crystal violet assay. First, the wells were washed twice with a saline solution $(0.9 \% \mathrm{NaCl}$ (Merck) in distilled water)) and then biofilms were fixed with $1 \mathrm{ml}$ of methanol (Merck) for $15 \mathrm{~min}$. After this time, methanol was removed and to each well was added $1 \mathrm{ml}$ of crystal violet $(1 \% \mathrm{v} / \mathrm{v}$, Merck) for $5 \mathrm{~min}$. The wells were then washed with water, and $1 \mathrm{ml}$ of acetic acid (33\% v/v, Merck) was added to dissolve the stain. The eluted stain was placed in a 96-well microtiter plate and its absorbance was read by an ELISA reader at $570 \mathrm{~nm}$. Two independent experiments were performed in duplicate.

\subsection{XTT reduction assay}

The determination of biofilm cellular activity was measured by the XTT reduction assay. Biofilms were washed twice with a saline solution $(0.9 \% \mathrm{NaCl}$ (Merck) in distilled water)) and then $1 \mathrm{ml}$ of XTT (200 $\mathrm{mg} \mathrm{l}^{-1}$, Sigma) solution plus PMS (20 $\mathrm{mg} \mathrm{l}^{-1}$, Sigma) was added to each well. The plates were incubated in the dark at $37{ }^{\circ} \mathrm{C}$ for $3 \mathrm{~h}$. After this time, the solution was removed from each well and placed in a 96-well microtiter plate to determine its absorbance at $490 \mathrm{~nm}$. Two independent experiments were performed in duplicate.

\subsection{Biofilm infection}

Biofilm infection was done with two different phages phiIBB-PAA2 and phiIBB-PAP21. After $24 \mathrm{~h}$ of biofilm formation, all medium and planktonic bacteria were removed from each well and washed with fresh YPD medium. Following that, $500 \mu \mathrm{l}$ of fresh YPD medium and $500 \mu \mathrm{l}$ of phage solution or $500 \mu \mathrm{l}$ of SM buffer in the case of control experiments were added. The m.o.i. used for both phages was 1. The plates were incubated in an orbital shaker $(120 \mathrm{rpm})$ at $37^{\circ} \mathrm{C}$ and samples were taken after 2,6 and $24 \mathrm{~h}$ of infection for $\mathrm{CFU}$ and PFU counts. Three independent experiments were performed in duplicate.

\subsection{0. $C F U$ and PFU counts}

To determine the amounts of bacteria present in biofilms, CFU counts was performed using the microdrop technique. Briefly, wells of the microplates were washed once with saline solution $(0.9 \% \mathrm{NaCl})$ to remove unattached bacteria and then $1 \mathrm{ml}$ of fresh saline solution was added to each well and the biofilm scraped with a cell scraper prior to sonication (5 min). After this, the cellular suspension of each well was removed, centrifuged $\left(5 \mathrm{~min}, 9000 \times \mathrm{g}, 4^{\circ} \mathrm{C}\right)$ and the pellet resuspended in $1 \mathrm{ml}$ of saline solution $(0.9 \%)$. The samples were diluted in saline solution $(0.9 \%)$ and one drop $(10 \mu \mathrm{l})$ was placed in a Petri plate containing YPD solid medium and allowed to run down the plate. Plates were incubated at $37{ }^{\circ} \mathrm{C}$ for $16-18 \mathrm{~h}$ and after CFUs were counted. For PFU counting, the small drop method described by Mazzoco et al. with some modifications was used (Mazzocco et al., 2008). Briefly, $20 \mu \mathrm{l}$ of diluted phage solution were added to $20 \mu \mathrm{l}$ of the overnightgrown host and incubated for $15-20 \mathrm{~min}$ to allow phage binding to the host. After this, $20 \mu \mathrm{l}$ of sample was placed in an agar plate and allowed to dry. Plates were incubated overnight at $37{ }^{\circ} \mathrm{C}$. Three independent experiments were performed in duplicate.

\subsection{Statistical analysis}

To compare the amounts of viable cells present in biofilms, analysis of variance (ANOVA single factor from MS Office) was used. In all analyses performed, the confidence interval used was $95 \%$.

\section{Results}

\subsection{Phage characterization}

Initially, 17 phages were isolated from hospital effluents by enrichment with 4 strains of $P$. aeruginosa. Characteristics of these phages were determined by the diameter and turbidity of phage plaques and the presence of a halo (Table 1). From the group of isolated phages, there were approximately the same number of phages responsible for clear ( 9 phages) and turbid (8 phages) plaques. Furthermore, some phages formed large plaques (ex: phiIBB-PAC24) while others had more pinhole characteristic (ex. phiIBB-PAP21) plaque morphology. Furthermore, most isolated phages were non halo-generating ones.

After characterizing the morphology of phage plaques, newly isolated phages were also tested against altogether 35 antibiotic-resistant clinical and reference strains of $P$. aeruginosa in order to study their lytic spectra (Table 2). Most phages showed lytic activity against several isolates, even against strains resistant to most of the 7 antibiotics tested, such as 
Table 2

Lytic spectra of newly isolated phages against reference and clinical strains of $P$. aeruginosa.

\begin{tabular}{|c|c|c|c|c|c|c|c|c|c|c|c|c|c|c|c|c|c|c|}
\hline \multicolumn{19}{|c|}{ Phage (phiIBB-...) } \\
\hline Host & Antibiog $^{a}$ & PAP21 & PAP121 & PAP221 & PAP2221 & PAP2222 & PAA2 & PAC24 & $\mathrm{PAC} 23$ & PAC111 & PAC222 & PAC2211 & PAC2212 & PACL11 & PACL12 & PACL22 & PACL211 & PACL212 \\
\hline PAO 1 & nd & $\mathrm{C}$ & $\mathrm{T}$ & $\mathrm{T}$ & $\mathrm{T}$ & $\mathrm{T}$ & - & $\mathrm{T}$ & $\mathrm{C}$ & - & $\mathrm{C}$ & - & $\mathrm{T}$ & - & $\mathrm{T}$ & - & - & - \\
\hline ATCC 10145 & nd & $\mathrm{C}$ & $\mathrm{C}$ & $\mathrm{T}$ & $\mathrm{C}$ & $\mathrm{C}$ & $\mathrm{T}$ & $\mathrm{C}$ & $\mathrm{C}$ & $\mathrm{C}$ & $\mathrm{T}$ & $\mathrm{T}$ & $\mathrm{C}$ & - & - & - & - & - \\
\hline CECT 111 & nd & $\mathrm{T}$ & - & - & - & - & $\mathrm{T}$ & $\mathrm{C}$ & $\mathrm{C}$ & $\mathrm{C}$ & $\mathrm{T}$ & $\mathrm{T}$ & $\mathrm{C}$ & - & - & - & - & - \\
\hline CLIN & nd & $\mathrm{T}$ & $\mathrm{T}$ & - & $\mathrm{T}$ & - & $\mathrm{T}$ & $\mathrm{T}$ & $\mathrm{T}$ & $\mathrm{T}$ & $\mathrm{T}$ & - & - & $\mathrm{T}$ & $\mathrm{T}$ & $\mathrm{T}$ & $\mathrm{T}$ & $\mathrm{T}$ \\
\hline 1 & 54 & $\mathrm{~T}$ & $\mathrm{C}$ & $\mathrm{T}$ & $\mathrm{C}$ & $\mathrm{T}$ & $\mathrm{C}$ & $\mathrm{C}$ & $\mathrm{C}$ & $\mathrm{C}$ & $\mathrm{C}$ & $\mathrm{C}$ & $\mathrm{C}$ & - & $\mathrm{C}$ & - & - & - \\
\hline 2 & 0 & - & $\mathrm{T}$ & - & - & - & $\mathrm{C}(\mathrm{RB})$ & $\mathrm{T}$ & $\mathrm{T}$ & $\mathrm{T}$ & $\mathrm{T}$ & $\mathrm{T}$ & $\mathrm{T}$ & - & - & - & - & - \\
\hline 3 & 14 & $\mathrm{C}$ & - & - & - & - & $\mathrm{C}$ & $\mathrm{C}$ & $\mathrm{C}$ & $\mathrm{C}$ & $\mathrm{C}$ & $\mathrm{C}$ & $\mathrm{C}$ & - & & - & - & - \\
\hline 4 & 0 & $\mathrm{C}$ & - & $\mathrm{C}$ & $\mathrm{C}$ & $\mathrm{T}$ & $\mathrm{T}$ & $\mathrm{T}$ & $\mathrm{T}$ & $\mathrm{T}$ & $\mathrm{T}$ & - & - & - & - & - & - & - \\
\hline 5 & 14 & $\mathrm{C}$ & $\mathrm{T}$ & $\mathrm{C}$ & $\mathrm{T}$ & $\mathrm{T}$ & $\mathrm{T}$ & $\mathrm{C}(\mathrm{RB})$ & $\mathrm{C}(\mathrm{RB})$ & $\mathrm{C}(\mathrm{RB})$ & $\mathrm{T}$ & $\mathrm{T}$ & $\mathrm{C}(\mathrm{RB})$ & $\mathrm{T}$ & $\mathrm{T}$ & $\mathrm{T}$ & $\mathrm{T}$ & $\mathrm{T}$ \\
\hline 6 & 0 & $\mathrm{C}$ & $\mathrm{C}$ & $\mathrm{C}$ & $\mathrm{T}$ & $\mathrm{T}$ & $\mathrm{C}(\mathrm{RB})$ & $\mathrm{C}(\mathrm{RB})$ & $\mathrm{C}(\mathrm{RB})$ & $\mathrm{C}(\mathrm{RB})$ & $\mathrm{T}$ & $\mathrm{T}$ & $\mathrm{T}$ & $\mathrm{C}$ & $\mathrm{C}$ & - & $\mathrm{C}$ & $\mathrm{C}$ \\
\hline 7 & 29 & $\mathrm{C}(\mathrm{RB})$ & - & - & - & - & $\mathrm{C}(\mathrm{RB})$ & $\mathrm{C}$ & $\mathrm{C}$ & $\mathrm{C}$ & $\mathrm{C}$ & $\mathrm{T}$ & $\mathrm{C}(\mathrm{RB})$ & - & $\mathrm{C}$ & - & - & - \\
\hline 8 & 0 & $\mathrm{C}$ & $\mathrm{C}$ & $\mathrm{C}$ & $\mathrm{T}$ & - & $\mathrm{C}$ & $\mathrm{C}$ & $\mathrm{C}(\mathrm{RB})$ & $\mathrm{C}(\mathrm{RB})$ & $\mathrm{C}(\mathrm{RB})$ & - & $\mathrm{C}$ & - & $\mathrm{C}$ & - & - & - \\
\hline 9 & 0 & - & - & - & - & - & $\mathrm{T}$ & $\mathrm{T}$ & $\mathrm{T}$ & $\mathrm{T}$ & $\mathrm{T}$ & $\mathrm{T}$ & $\mathrm{T}$ & - & - & - & - & - \\
\hline 10 & 43 & - & $\mathrm{T}$ & $\mathrm{T}$ & $\mathrm{T}$ & - & $\mathrm{T}$ & $\mathrm{T}$ & $\mathrm{T}$ & - & - & $\mathrm{T}$ & - & $\mathrm{T}$ & $\mathrm{T}$ & $\mathrm{T}$ & $\mathrm{T}$ & - \\
\hline 11 & 57 & $\mathrm{C}$ & $\mathrm{C}$ & $\mathrm{C}$ & $\mathrm{C}$ & $\mathrm{C}$ & $\mathrm{T}$ & $\mathrm{T}$ & $\mathrm{T}$ & $\mathrm{T}$ & $\mathrm{C}$ & $\mathrm{C}$ & $\mathrm{C}$ & - & $\mathrm{C}$ & - & - & - \\
\hline 12 & 86 & C & $\mathrm{T}$ & $\mathrm{T}$ & $\mathrm{T}$ & $\mathrm{T}$ & $\mathrm{T}$ & $\mathrm{T}$ & $\mathrm{T}$ & $\mathrm{T}$ & - & - & $\mathrm{T}$ & $\mathrm{C}$ & - & $\mathrm{C}(\mathrm{RB})$ & $\mathrm{T}$ & $\mathrm{T}$ \\
\hline 13 & 14 & - & - & - & - & $\mathrm{T}$ & $\mathrm{T}$ & C & $\mathrm{C}$ & $\mathrm{C}$ & $\mathrm{C}$ & $\mathrm{C}$ & $\mathrm{C}$ & - & - & - & - & - \\
\hline 14 & 14 & - & - & - & - & - & - & $\mathrm{T}$ & $\mathrm{T}$ & - & - & - & - & - & - & - & - & - \\
\hline 15 & 0 & - & - & - & - & - & $\mathrm{T}$ & $\mathrm{T}$ & $\mathrm{T}$ & - & $\mathrm{T}$ & $\mathrm{T}$ & $\mathrm{T}$ & - & - & - & - & - \\
\hline 16 & 0 & C & C & C & C & C & $\mathrm{C}(\mathrm{RB})$ & C & C & $\mathrm{T}$ & C & $\mathrm{T}$ & - & - & C & - & - & $\mathrm{T}$ \\
\hline 17 & 86 & $\mathrm{C}$ & $\mathrm{T}$ & - & $\mathrm{T}$ & C & $\mathrm{C}(\mathrm{RB})$ & $\mathrm{C}$ & C & $\mathrm{C}(\mathrm{RB})$ & $\mathrm{C}$ & - & - & - & - & - & - & - \\
\hline 18 & 29 & $\mathrm{C}$ & $\mathrm{C}$ & $\mathrm{C}$ & $\mathrm{C}(\mathrm{RB})$ & C & $\mathrm{T}$ & - & - & $\mathrm{T}$ & - & - & - & - & $\mathrm{C}(\mathrm{RB})$ & - & - & - \\
\hline 19 & 71 & - & - & - & - & - & $\mathrm{T}$ & $\mathrm{T}$ & $\mathrm{T}$ & - & $\mathrm{T}$ & - & - & - & - & - & - & - \\
\hline 20 & 0 & $\mathrm{~T}$ & $\mathrm{~T}$ & $\mathrm{~T}$ & $\mathrm{~T}$ & $\mathrm{~T}$ & - & - & $\mathrm{T}$ & - & $\mathrm{T}$ & $\mathrm{T}$ & - & $\mathrm{T}$ & $\mathrm{T}$ & $\mathrm{T}$ & $\mathrm{T}$ & $\mathrm{T}$ \\
\hline 21 & 0 & $\mathrm{~T}$ & $\mathrm{~T}$ & $\mathrm{~T}$ & $\mathrm{~T}$ & C & $\mathrm{T}$ & $\mathrm{T}$ & - & $\mathrm{T}$ & - & $\mathrm{T}$ & $\mathrm{T}$ & $\mathrm{C}$ & $\mathrm{C}$ & - & - & $\mathrm{T}$ \\
\hline 22 & 0 & $\mathrm{~T}$ & $\mathrm{C}$ & $\mathrm{C}$ & $\mathrm{C}$ & $\mathrm{T}$ & - & - & - & - & - & $\mathrm{T}$ & - & - & $\mathrm{C}$ & - & - & - \\
\hline 23 & 14 & $\mathrm{~T}$ & - & $\mathrm{T}$ & - & $\mathrm{T}$ & $\mathrm{T}$ & $\mathrm{T}$ & $\mathrm{T}$ & $\mathrm{T}$ & $\mathrm{T}$ & - & - & - & - & - & - & - \\
\hline 24 & 14 & $\mathrm{~T}$ & - & - & - & - & $\mathrm{T}$ & $\mathrm{T}$ & $\mathrm{T}$ & - & $\mathrm{T}$ & - & - & - & - & - & - & - \\
\hline 25 & 86 & $\mathrm{C}$ & $\mathrm{C}$ & $\mathrm{C}$ & $\mathrm{C}$ & $\mathrm{C}$ & $\mathrm{C}$ & $\mathrm{C}$ & $\mathrm{C}$ & $\mathrm{T}$ & $\mathrm{C}$ & $\mathrm{T}$ & $\mathrm{T}$ & - & $\mathrm{C}$ & - & - & - \\
\hline 26 & 0 & $\mathrm{C}$ & $\mathrm{C}$ & $\mathrm{C}$ & $\mathrm{C}$ & $\mathrm{C}$ & $\mathrm{T}$ & $\mathrm{C}$ & $\mathrm{C}(\mathrm{RB})$ & $\mathrm{T}$ & $\mathrm{T}$ & $\mathrm{T}$ & $\mathrm{T}$ & - & $\mathrm{C}$ & - & - & - \\
\hline 27 & 0 & $\mathrm{~T}$ & C & $\mathrm{T}$ & C & C & C & C & C & $\mathrm{T}$ & C & $\mathrm{T}$ & $\mathrm{T}$ & - & C & - & - & - \\
\hline 28 & 14 & $\mathrm{~T}$ & - & - & - & - & $\mathrm{T}$ & $\mathrm{T}$ & $\mathrm{T}$ & $\mathrm{T}$ & $\mathrm{T}$ & $\mathrm{T}$ & $\mathrm{T}$ & - & - & - & - & - \\
\hline 29 & 0 & $\mathrm{~T}$ & $\mathrm{C}$ & $\mathrm{T}$ & $\mathrm{C}$ & $\mathrm{C}$ & $\mathrm{C}(\mathrm{RB})$ & $\mathrm{T}$ & $\mathrm{C}(\mathrm{RB})$ & $\mathrm{T}$ & $\mathrm{C}(\mathrm{RB})$ & - & - & - & $\mathrm{T}$ & - & - & - \\
\hline 30 & nd & $\mathrm{T}$ & $\mathrm{C}$ & $\mathrm{C}$ & $\mathrm{C}$ & $\mathrm{C}$ & - & - & - & - & - & - & - & - & $\mathrm{C}$ & - & - & - \\
\hline 31 & nd & $\mathrm{T}$ & $\mathrm{T}$ & $\mathrm{T}$ & - & $\mathrm{T}$ & $\mathrm{T}$ & $\mathrm{T}$ & $\mathrm{T}$ & $\mathrm{T}$ & - & $\mathrm{T}$ & $\mathrm{T}$ & $\mathrm{T}$ & - & $\mathrm{T}$ & - & $\mathrm{T}$ \\
\hline$\%$ Infection & & 80.00 & 65.71 & 62.86 & 62.86 & 62.86 & 85.71 & 88.57 & 88.57 & 74.29 & 77.14 & 62.86 & 60.00 & 22.86 & 54.29 & 17.14 & 17.14 & 22.86 \\
\hline
\end{tabular}

T: Turbid; C: Clear; $\mathrm{C}(\mathrm{RB})$ : Clear with resistant bacteria; nd: not determined.

${ }^{a}$ Percentage of resistance of the bacteria to 7 antibiotics used in the antibiogram - imipenem, ciprofloxacin, ceftazidime, gentamicin, amikacin, tazobactam, tobramycin. 
isolate numbers 12, 17, 19 and 25, respectively. Phages isolated for strain CECT 111 were shown to infect the highest number of strains used in this study. Nevertheless, some phages, and especially those isolated for the clinical strain of $P$. aeruginosa, had a narrower spectrum of activity (ex. phiIBB-PACL22 and phiIBB-PACL211) towards the tested isolates and therefore were considered less efficient. Although only one phage was isolated for the ATCC 10145 strain, phiIBB-PAA2 respectively, this phage proved to have a broad spectrum of activity, infecting $85.71 \%$ of the tested strains (see Table 2).

After lytic spectrum assays, one phage for each host was selected for use in planktonic and biofilm infection experiments. The criterion used for this selection was the number of strains that each phage was able to infect. Accordingly, the selected phages were: phiIBB-PAA2, phiIBB-PAC23, phiIBBPACL12 and phiIBB-PAP21, respectively. These phages were analysed by transmission electron microscopy (TEM) and presented a head size of $58 \mathrm{~nm}$ and a tail of $12 \mathrm{~nm} \times 8 \mathrm{~nm}$ characteristic of the Podoviridae family of phages (Fig. 1).

\subsection{Infection of planktonic cells}

After phage selection and characterization, phage infection experiments were performed in exponentially growing and stationary cells (Fig. 2). The growth of the 4 different Pseudomonas strains varied considerably. Since this experiment was performed using fresh media, an increase in optical density of stationary phase cells was also observed. The 4 phage-host systems showed a clear difference in the infection patterns of stationary and exponentially growing cells. Both phages phiIBB-PAA2 and phiIBB-PAP2 1 infected exponentially growing cells. Unlike phiIBB-PAP21, phage phiIBBPAA2, besides infecting exponential phase cells, was also

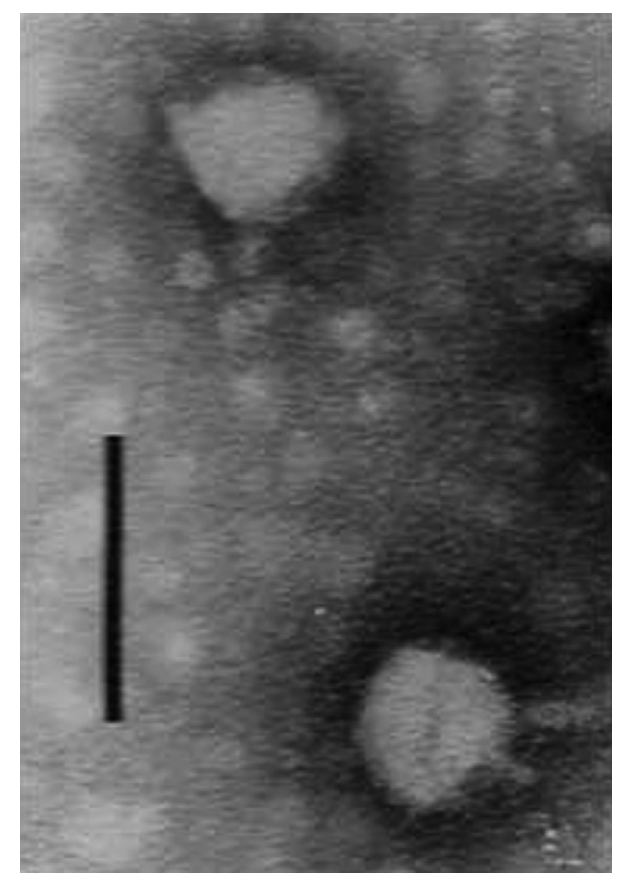

Fig. 1. Phage phiIBB-PAA2 observed by TEM. (Bar corresponds to $100 \mathrm{~nm}$ ). capable of lysing stationary phase cells. The infection of both stationary and exponential growth phase cells with phage phiIBB-PAC23 caused only a minor reduction in OD. Furthermore, strain CLIN continued to grow slowly even in the presence of phage phiBB-PACL12. Despite the last two mentioned phages, which were less efficient than phages phiIBB-PAA2 and phiIBB-PAP21, there was a significant difference in the infected cultures compared to the exponential and stationary controls, performed with SM buffer instead of the different phages.

\subsection{P. aeruginosa biofilm characteristics}

24- and 48-h-old $P$. aeruginosa biofilms were characterized in terms of biomass quantity by CV staining, CFU counts, and also through evaluation of metabolic activity by XTT reduction. The medium in both biofilms was renewed every $12 \mathrm{~h}$. Since phages phiIBB-PACL12 and phiIBB-PAC23 were less effective in lysing cells, only biofilms of $P$. aeruginosa ATCC 10145 and PAO 1 were characterized for further infection experiments with phages phiIBB-PAA2 and phiIBB-PAP21, respectively.

Biofilms of $P$. aeruginosa ATCC 10145 were characterized by having a higher amount of biomass attached to the surface of the 24 well-plate (Fig. 3A) than biofilms of P. aeruginosa PAO 1. There were no significant differences in the amount of total biomass existing in 24- and 48-h-old biofilms. In terms of metabolic activity, XTT results showed that 24-h-old biofilms of $P$. aeruginosa PAO 1 were more active than 48-h-old biofilms of this strain; however, 24 and $48 \mathrm{~h} \mathrm{P}$ aeruginosa ATCC 10145 biofilms resulted in similar values (Fig. 3B). The viable counts of both strains in the studied biofilms were statistically similar $(p=0.15)$. Furthermore, $24 \mathrm{~h}$ biofilms of $P$. aeruginosa ATCC 10145 had a significantly higher $(p=0.025)$ number of viable cells than biofilms formed for $48 \mathrm{~h}$ (Fig. 3C). Although, $24 \mathrm{~h}$ biofilms of PAO1 presented more viable cells, values compared to $48 \mathrm{~h}$ biofilms were not statistically different $(p=0.29)$.

\subsection{Biofilm infection}

Phage infection of P. aeruginosa ATCC 10145 and PAO1 was performed in $24 \mathrm{~h}$ biofilms (Fig. 4) due to the fairly similar amounts of viable cells present in 24 and $48 \mathrm{~h}$ PAO1 and ATCC 10145 biofilms (as described above). According to infection results, phage phiIBB-PAA2 gradually decreased the numbers of viable cells present in the biofilms; already after $2 \mathrm{~h}$, there was a statistically significant $(p=0.025)$ reduction in viable cells, which was further enhanced after 6 and $24 \mathrm{~h}$ of biofilm infection, achieving an almost 3-log reduction. Phage phiIBB-PAP21 caused a considerably greater reduction ( $p=0.0008)$ in P. aeruginosa PAO1 biofilm cells after $2 \mathrm{~h}$ of infection compared to reduction of $P$. aeruginosa ATCC 10145 infected with phiIBB-PAA2. The reduction of $P$. aeruginosa PAO1 biofilms due to philBB-PAP21 continued until $6 \mathrm{~h}$ of biofilm treatment; however, biofilm cells acquired resistance to the phage and consequently, the numbers of cells after $24 \mathrm{~h}$ of infection increased. 

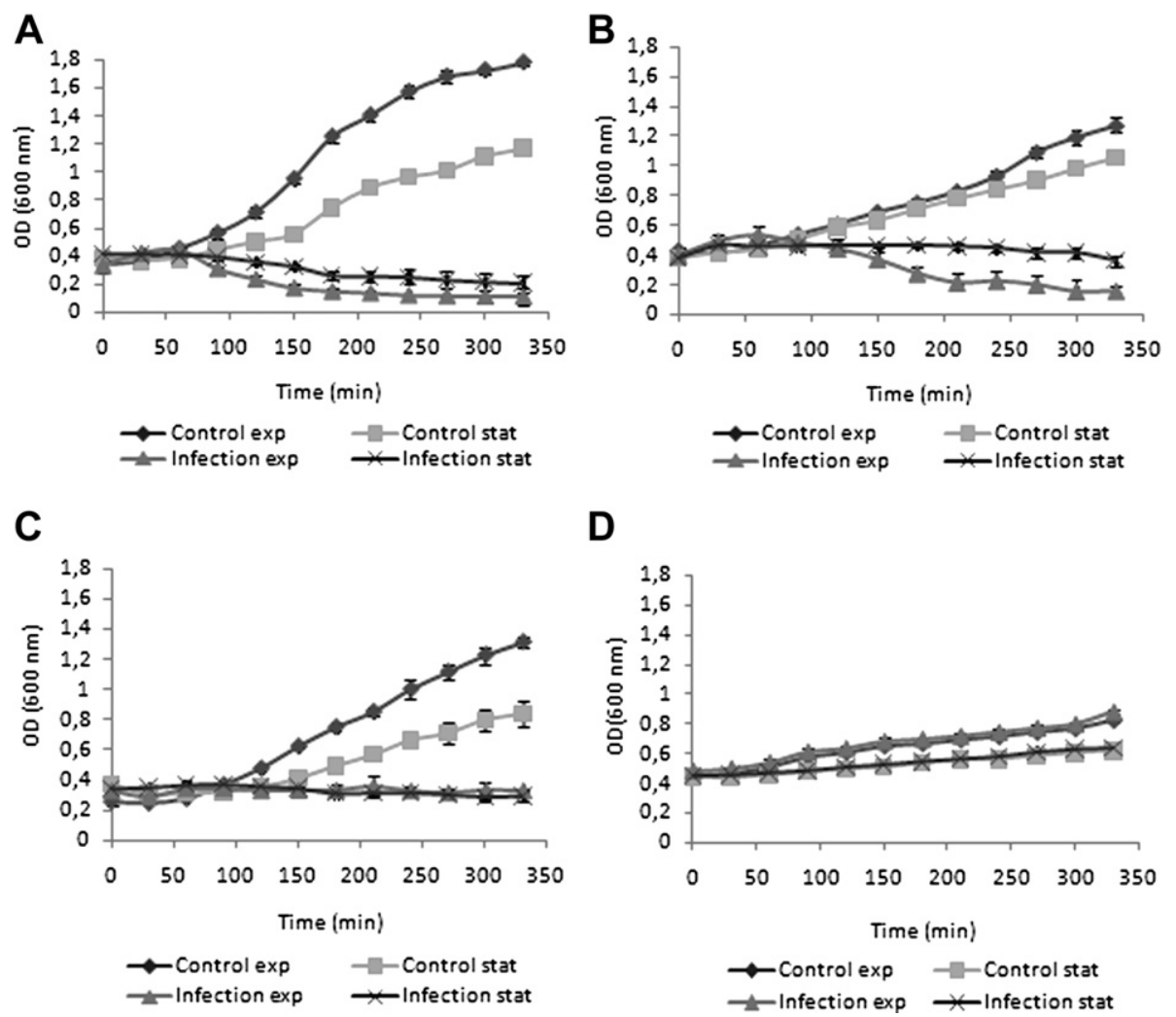

Fig. 2. Infection of planktonic P. aeruginosa cultures with phages: A) phiIBB-PAA2 (ATCC 10145), B) phiIBB-PAP21 (PAO1), C) phiIBB-PAC23 (CECT 111), and D) phiIBB-PACL12 (CLIN) in exponential and stationary growth using a MOI 1. Error bars represent standard deviations from 3 independent experiments performed in duplicate.

One unexpected result occurred in the number of phages attached to the biofilms (and the surface of the well) as measured by plaque-forming unit (PFU) counts. After $2 \mathrm{~h}$ of infection, higher amounts of phage phiIBB-PAA2 than phage philBB-PaP21 were observed entrapped in the biofilms. Experiments performed in 24-well microtiter plates in the absence of $P$. aeruginosa cells, showed that philBB-PAA2 attached more rapidly to the well substrata (data not shown). This can explain the weaker reduction in the amount of viable cells of $P$. aeruginosa ATCC 10145 by phage phiIBB-PAA2, since phages attached to the substrata far from biofilm cells will not cause their lysis. The number of phage phiIBB-PAA2 entrapped in the biofilms (and substrata) decreased throughout the $24 \mathrm{~h}$ experiment by approximately 1.7 logs. Unlike phage
phiIBB-PAA2, the amount of phiIBB-PAP21 phages adsorbed increased until $6 \mathrm{~h}$ of infection. Nevertheless, as in phiIBBPAA2 experiments, also after $24 \mathrm{~h}$ of biofilm cell infection, the number of phages attached was significantly lower.

The time for biofilm cell resistance toward phages was compared with the resistance acquired by planktonic cells (Fig. 5). After approximately $9-10 \mathrm{~h}$ of infection, planktonic $P$. aeruginosa PAO1 cell cultures began to grow again. Both colonies of planktonic and biofilm experiments were tested with phage stock solution, and all showed resistance to phiIBB-PAP21. Despite the lack of resistance of $P$. aeruginosa ATCC 10145 biofilms after $24 \mathrm{~h}$ of exposure to phage phiIBBPAA2, acquisition of resistance by planktonic cultures to the phage was observed.
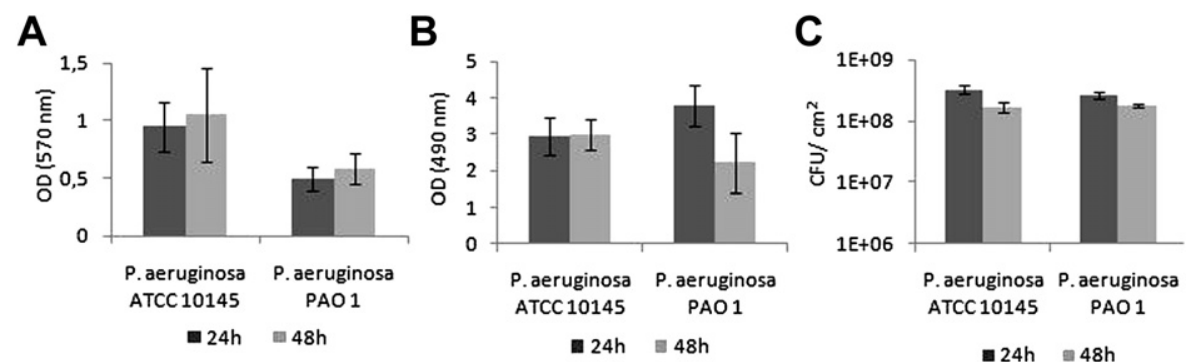

Fig. 3. Characterization of P. aeruginosa ATCC 10145 and PAO1 biofilms formed for 24 and $48 \mathrm{~h}$. A) Biomass quantification using CV staining; B) evaluation of biofilm metabolic activity by XTT; C) enumeration of the number of viable cells present in the biofilms. The error bars represent standard deviations from 3 independent experiments performed in duplicate. 
A

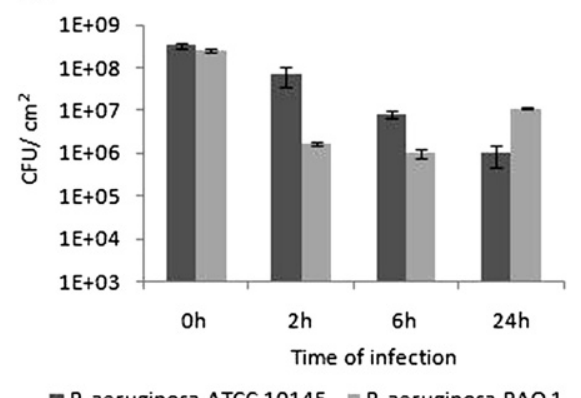

B

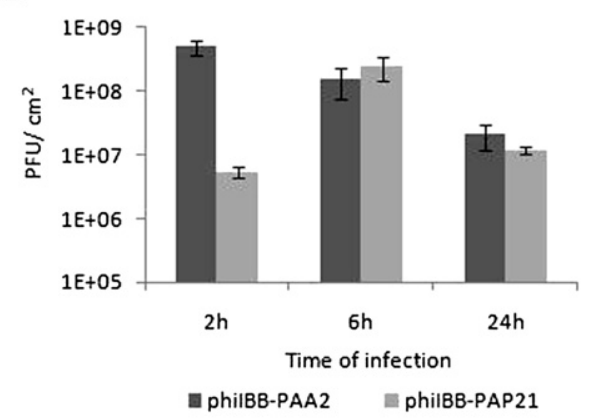

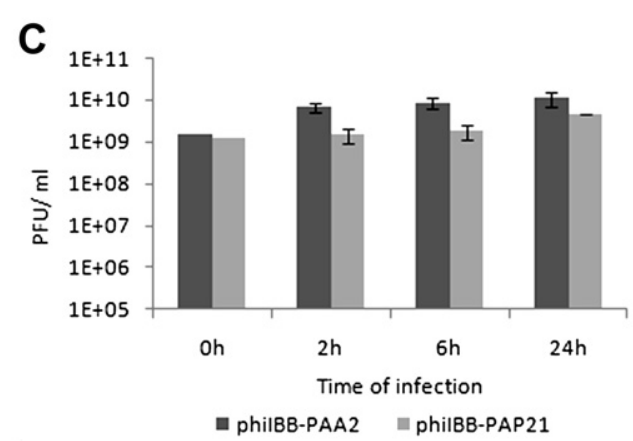

Fig. 4. Infection of P. aeruginosa ATCC 10145 and PAO1 biofilms with phages phiIBB-PAA2 and phiIBB-PAP21, respectively. A) Number of viable cells before and after infection; B) number of phages (PFU) present in the biofilms; C) number of phages (PFU) released from infected biofilms. The error bars represent standard deviations from 3 independent experiments performed in duplicate.

\section{Discussion}

The development of new alternatives to antibiotherapy for eradication and control of virulent biofilms from surfaces, mainly of medical devices, has become a great challenge in the scientific community. Several studies have shown the potential of use of phages to treat infectious diseases in animals (Loc Carrillo et al., 2005; McVay et al., 2007; Nakai and Park, 2002; Wagenaar et al., 2005) and humans (WeberDabrowska et al., 1987, 2001), even those caused by antibiotic-resistant bacteria (Weber-Dabrowska et al., 2003).

In the present study, 17 new phages for $P$. aeruginosa were isolated from hospital effluents using three collection strains

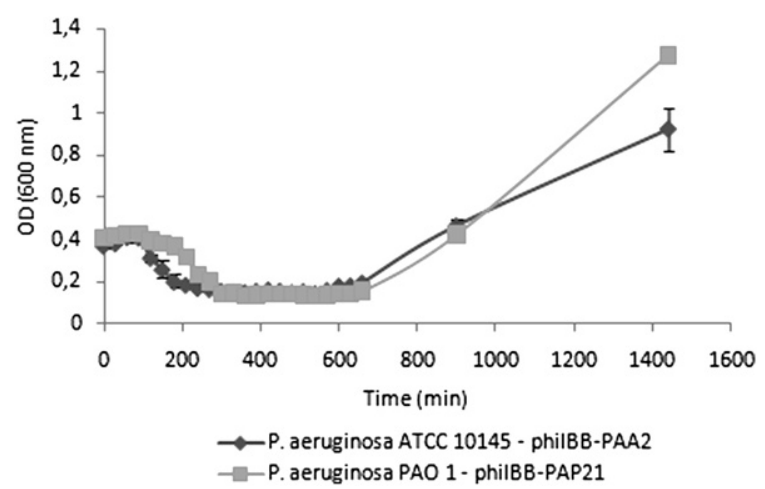

Fig. 5. Infection of $P$. aeruginosa ATCC 10145 and PAO1 planktonic cultures with phages phiIBB-PAA2 and phiIBB-PAP21, respectively, using an m.o.i. of 1 for $25 \mathrm{~h}$. and a clinical strain and they were tested for efficiency against 35 clinical strains. The least efficient isolated phages were those with the clinical $P$. aeruginosa isolate as host, where the percentages of strains infected varied between 17 and 54 percent, while the most efficient phages, those with CECT 111 as propagating strain, were capable of lysing approximately 60-89 percent of the clinical strains tested. These percentages are significantly above those observed by Knezevic et al. for 19 newly isolated $P$. aeruginosa phages which were found to be capable of killing up to 75.8 percent of 33 strains isolated from humans (21), animals (1), the environment (10) and 1 culture strain (ATCC 9027) (Knezevic et al., 2009).

Based on the efficiency of killing clinical strains, four lytic phages were selected for further characterization and used in infection assays against planktonic and biofilm cells. Despite the broad spectra of activity of the selected phages against clinical $P$. aeruginosa isolates, infection experiments on planktonic cultures showed, surprisingly, that two of them failed to infect their hosts even at the ideal bacterial growth phase-the exponential phase. This suggests that, although phages can be selected based on their broad activity, this does not necessarily guarantee their effectiveness in controlling their respective host population. Nevertheless, two of the used phages, phages phiIBB-PAA2 and phiIBB-PAP21, were both efficient towards exponential as well as stationary phase cells and caused over a 50\% reduction in initial OD. Yet phage phiIBB-PAP21 revealed a slightly weaker ability to infect $P$. aeruginosa $\mathrm{PAO} 1$ planktonic cells than phage phiIBB-PAA2 for strain ATCC 10145. It has been frequently reported, with different phage-host systems, that there is reduced lysis when 
cells are near the stationary phase (Abedon and Yin, 2009; Burch and Chao, 2004; Middelboe, 2000; Ricciuti, 1972; Sillankorva et al., 2004). For instance, the T4 phage cannot even produce a burst if Escherichia coli cells are in the stationary phase (Delbrück, 1940). The main factors accounting for reduction of lysis in stationary cells are: fewer phage-adsorption sites, lower phage progeny per infection and reduced cell lysis due to cell wall thickness or increased nonviable infections (Weitz and Dushoff, 2008). Thus, our results are extremely interesting, as they demonstrate that some, but not all "T7-like" phages can be effective against stationary phase cells.

It is not surprising that phage infection in planktonic cells is more efficient than in biofilms due to biofilm architecture, which prevents easy access by phages to the bacteria (Hanlon et al., 2001). Due to the inefficient activity of phages phiIBBPACL12 and phiIBB-PAC23 against planktonic cultures, only two phages, phiIBB-PAA2 and phiIBB-PAP21, were chosen for $P$. aeruginosa biofilm control experiments. Both phages, tested against $24 \mathrm{~h}$ biofilms, caused significant reduction on biofilm cells already after $2 \mathrm{~h}$ of infection and the reduction was further enhanced after $6 \mathrm{~h}$ of biofilm treatment, reaching a reduction of almost $3 \log$ by phage phiIBB-PAP2 1 and a 2 $\log$ reduction by phage phiIBB-PAA2. Although our approach was different, viable cell reductions achieved were similar to those reported by Fu et al., where P. aeruginosa phages were used to prevent biofilm formation on hydrogel-coated catheter surfaces. Accordingly, Fu et al., after 24 h, achieved a 2.84-log lower number of viable cells on phage pre-treated catheters than on untreated catheters (Fu et al., 2010).

Despite lower activity against planktonic cells, phage phiIBB-PAP21 caused a stronger reduction in viable cells from $P$. aeruginosa PAO1 biofilms after 2 and $6 \mathrm{~h}$ of treatment than phage phiIBB-PAA2 in P. aeruginosa ATCC 10145 biofilms. Similar reductions in viable cells have been observed for Pseudomonas fluorescens phages (Sillankorva et al., 2004) and there is only one work in the literature where complete eradication of $24 \mathrm{~h}$ Enterobacter cloace biofilms by a combination of 3 different phages was achieved (Tait et al., 2002). The main difference between the two phages used in our work for $P$. aeruginosa biofilm control experiments, concerns resistance to phages. The interaction of phages and bacteria during long periods of time can result in the emergence of phage-resistant bacteria (Bohannan and Lenski, 2000; Buckling and Rainey, 2002). Biofilm cells of $P$. aeruginosa PAO1, the host of phage phiIBB-PAP21, acquired resistance to the phage, resulting in an increase in the number of cells after $24 \mathrm{~h}$ of biofilm treatment. To evaluate the period when resistance starts appearing in planktonic cultures, $P$. aeruginosa PAO1 planktonic cells infected with phage phiIBB-PAP21 showed that resistance appeared after approximately $9-10 \mathrm{~h}$ of infection, which is in accordance with biofilm results showing the emergence of resistance between 6 and $24 \mathrm{~h}$. On the other hand, phage phiIBB-PAA2 continued to destroy biofilm cells of $P$. aeruginosa ATCC 10145 and there was no evidence of biofilm cells becoming resistant even after $24 \mathrm{~h}$ of phage infection. Unlike experiments with $P$. aeruginosa ATCC
10145 biofilms, assays performed with planktonic cells and phage phiIBB-PAA2 resulted in increased resistance to this phage. In $24 \mathrm{~h} P$. aeruginosa ATCC 10145 biofilms, most likely there are already some resistant phenotypes; however, their growth is possibly slower and thus, non-randomly selected and tested colonies showed resistance to phage phiIBB-PAA2. Further studies will be performed to understand and confirm the phenomenon of increased resistance of planktonic cells, compared to biofilm cells.

Thus, this study reveals that both novel isolated phages were capable of controlling $P$. aeruginosa biofilms; however, short periods of treatment seem to be a better solution for avoiding the emergence of phage-resistant hosts. In addition, use of phage cocktails presented advantages over use of single cells, since phages can be selected in such a way as to overwhelm host resistance mutations.

\section{Acknowledgements}

The authors gratefully acknowledge the Hospital de Braga for providing $P$. aeruginosa clinical strains. The authors are also grateful to Dr. Hans Ackermann for morphological characterization of the phages.

\section{References}

Abedon, S.T., Yin, J., 2009. M.R. Clokie and A.M. Kropinski. Bacteriophage Plaques: Theory and Analysis. Bacteriophages Methods and Protocols, 1. Springer-Verlag, New York. 161-174.

Azeredo, J., Sutherland, I.W., 2008. The use of phages for the Removal of infectious biofilms. Curr. Pharm. Biotechnol. 9, 261-266.

Bohannan, B.J.M., Lenski, R.E., 2000. Linking genetic change to community evolution: insights from studies of bacteria and bacteriophage. Ecol. Lett. 3, 362-377.

Buckling, A., Rainey, P.B., 2002. Antagonistic coevolution between a bacterium and a bacteriophage. Proc. Biol. Sci. 269, 931-936.

Burch, C.L., Chao, L., 2004. Epistasis and its Relationship to Canalization in the RNA virus f6. Genetics 167, 559-567.

Clark, J.R., March, J.B., 2006. Bacteriophages and biotechnology: vaccines, gene therapy and antibacterials. Trends Biotechnol. 24, 212-218.

Cunha, B.A., 2002. Pseudomonas aeruginosa: resistance and therapy. Semin. Respir. Infect. 17, 231-239.

Delbrück, M., 1940. Adsorption of bacteriophage under various phisiological conditions of the host. J. Gen. Physiol. 23, 631-642.

Donlan, R.M., 2002. Biofilms: microbial life on surfaces. Emerg. Infect. Dis. $8,881-890$.

Drenkard, E., 2003. Antimicrobial resistance of Pseudomonas aeruginosa biofilms. Microbes Infect. 5, 1213-1219.

Driscoll, J.A., Brody, S.L., Kollef, M.H., 2007. The epidemiology, pathogenesis and treatment of Pseudomonas aeruginosa infections. Drugs 67, $351-368$.

Fu, W., Forster, T., Mayer, O., Curtin, J.J., Lehman, S.M., Donlan, R.M., 2010. Bacteriophage cocktail for the Prevention of biofilm formation by Pseudomonas aeruginosa on catheters in an in vitro model System. Antimicrob. Agents Chemother. 54, 397-404.

Hanlon, G.W., Denyer, S.P., Olliff, C.J., Ibrahim, L.J., 2001. Reduction in Exopolysaccharide Viscosity as an Aid to bacteriophage penetration through Pseudomonas aeruginosa biofilms. Appl. Environ. Microbiol. 67, 2746-2753.

Joerger, R.D., 2003. Alternatives to antibiotics: bacteriocins, antimicrobial peptides and bacteriophages. Poult. Sci. 82, 640-647. 
Knezevic, P., Kostanjsek, R., Obreht, D., Petrovic, O., 2009. Isolation of Pseudomonas aeruginosa specific phages with broad activity spectra. Curr. Microbiol. 59, 173-180.

Lambert, P.A., 2002. Mechanisms of antibiotic resistance in Pseudomonas aeruginosa. J. R. Soc. Med. 95, 22-26.

Loc Carrillo, C., Atterbury, R.J., El-Shibiny, A., Connerton, P.L., Dillon, E., Scott, A., Connerton, I.F., 2005. Bacteriophage therapy to reduce Campylobacter jejuni colonization of Broiler Chickens. Appl. Environ. Microbiol. 71, 6554-6563.

Mah, T.F., Pitts, B., Pellock, B., Walker, G.C., Stewart, P.S., O’Toole, G.A., 2003. A genetic basis for Pseudomonas aeruginosa biofilm antibiotic resistance. Nature 426, 306-310.

Matsuzaki, S., Rashel, M., Sakurai, S., Ujihara, T., Kuroda, M., Ikeuchi, M., Tani, T., Fujieda, M., Wakiguchi, H., Imai, S., 2005. Bacteriophage therapy: a revitalized therapy against bacterial infectious diseases. J. Infect. Chemother. 11, 211-219.

Mazzocco, A., Waddell, T.E., Lingohr, E., Johnson, R.P., 2008. Enumeration of Bacteriophages Using the Small Drop Plaque Assay System. Bacteriophages: Methods and Protocols. In: Isolation, Characterization and Interactions, vol. 1. Humana Press. 81-85.

McVay, C.S., Velasquez, M., Fralick, J.A., 2007. Phage therapy of Pseudomonas aeruginosa infection in a mouse burn wound model. Antimicrob. Agents Chemother. 51, 1934-1938.

Middelboe, M., 2000. Bacterial growth Rate and Marine Virus-Host dynamics. Microb. Ecol. 40, 114-124.

Nakai, T., Park, S.C., 2002. Bacteriophage therapy of infectious diseases in aquaculture. Res. Microbiol. 153, 13-18.

O’Toole, G., Kaplan, H., Kolter, R., 2000. Biofilm formation as microbial development. Annu. Rev. Microbiol. 54, 49-79.
Page, M.G.P., Heim, J., 2009. Prospects for the next anti-Pseudomonas drug. Curr. Opin. Pharmacol. 9, 558-565.

Ricciuti, C.P., 1972. Host-virus interactions in Escherichia coli: effect of stationary phase on viral release from MS2-infected bacteria. J. Virol. 10, $162-165$.

Sillankorva, S., Oliveira, R., Vieira, M.J., Sutherland, I., Azeredo, J., 2004. Bacteriophage $\Phi$ S1 infection of Pseudomonas fluorescens planktonic cells versus biofilms. Biofouling 20, 133-138.

Skurnik, M., Strauch, E., 2006. Phage therapy: facts and fiction. Int. J. Med. Microbiol. 296, 5-14.

Stewart, P.S., William Costerton, J., 2001. Antibiotic resistance of bacteria in biofilms. Lancet 358, 135-138.

Sulakvelidze, A., 2005. Phage therapy: an attractive option for dealing with antibiotic-resistant bacterial infections. Drug Discov. Today 10, 807-809.

Tait, K., Skillman, L.C., Sutherland, I.W., 2002. The efficacy of bacteriophage as a method of biofilm eradication. Biofouling 18, 305-311.

Wagenaar, J.A., Bergen, M.A.P.V., Mueller, M.A., Wassenaar, T.M., Carlton, R.M., 2005. Phage therapy reduces Campylobacter jejuni colonization in broilers. Vet. Microbiol. 109, 275-283.

Weber-Dabrowska, B., Dabrowski, M., Slopek, S., 1987. Studies on bacteriophage penetration in patients subjected to phage therapy. Arch. Immunol. Ther. Exp. 35, 563-568.

Weber-Dabrowska, B., Mulczyk, M., Górski, A., 2001. Bacteriophage therapy for infections in cancer patients. Clin. Appl. Immunol. Rev. 1, 131-134.

Weber-Dabrowska, B., Mulczyk, M., Górski, A., 2003. Bacteriophages as an efficient therapy for antibiotic-resistant septicemia in man. Transplant Proceed 35, 1385-1386.

Weitz, J., Dushoff, J., 2008. Alternative stable states in host-phage dynamics. Theor. Ecol. 1, 13-19. 